BNL-77302-2006

FORMAL REPORT

\title{
MOLECULAR MECHANISM OF URANIUM REDUCTION BY CLOSTRIDIA AND ITS MANIPULATION
}

\section{(ANNUAL REPORT)}

\author{
A. J. Francis (PI), W. Gao, D. Chidambaram, and C. J. Dodge
}

November 2006

\author{
Environmental Sciences Department \\ Environmental Research \& Technology Division \\ Brookhaven National Laboratory \\ P.O. Box 5000 \\ Upton, NY 11973-5000 \\ www.bnl.gov
}

Notice: This manuscript has been authored by employees of Brookhaven Science Associates, LLC under Contract No. DE-AC0298CH10886 with the U.S. Department of Energy. The publisher by accepting the manuscript for publication acknowledges that the United States Government retains a non-exclusive, paid-up, irrevocable, world-wide license to publish or reproduce the published form of this manuscript, or allow others to do so, for United States Government purposes. 


\section{DISCLAIMER}

This report was prepared as an account of work sponsored by an agency of the United States Government. Neither the United States Government nor any agency thereof, nor any of their employees, nor any of their contractors, subcontractors, or their employees, makes any warranty, express or implied, or assumes any legal liability or responsibility for the accuracy, completeness, or any third party's use or the results of such use of any information, apparatus, product, or process disclosed, or represents that its use would not infringe privately owned rights. Reference herein to any specific commercial product, process, or service by trade name, trademark, manufacturer, or otherwise, does not necessarily constitute or imply its endorsement, recommendation, or favoring by the United States Government or any agency thereof or its contractors or subcontractors. The views and opinions of authors expressed herein do not necessarily state or reflect those of the United States Government or any agency thereof. 


\title{
Molecular Mechanism of Uranium Reduction by Clostridia and its Manipulation
}

\author{
A. J. Francis (PI), W. Gao, D. Chidambaram, and C.J. Dodge \\ Environmental Sciences Department, Brookhaven National Laboratory, Upton, NY 11973
}

\section{RESEARCH OBJECTIVES}

This research addresses the need for detailed studies of the enzymatic mechanisms for reduction of radionuclides and/or metals by fermentative microorganisms. The overall objective of this research is to elucidate systematically the molecular mechanisms involved in the reduction of uranium by Clostridia. We propose to (i) determine the role of hydrogenases in uranium reduction, (ii) purify the enzymes involved in uranium reduction, (iii) determine the mechanisms of reduction, e.g., one or two electron transfer reactions, and (iv) elucidate the genetic control of the enzymes and cellular factors involved in uranium reduction.

This is a collaborative study between BNL and Stanford University involving expertise in biomolecular science, biochemistry, microbiology, and electrochemistry.

\section{RESEARCH PROGRESS AND IMPLICATIONS}

This report summarizes the work after 1 year of a 3 year project. We have accomplished the following goals during the first year of this project:

\section{REDUCTION OF URANIUM (VI) BY CLOSTRIDIA.}

In this study, we determined the ability of different Clostridia species to reduce U(VI) to U(IV). Four strains were used in this study. Clostridium sp. (ATCC 53464), which was

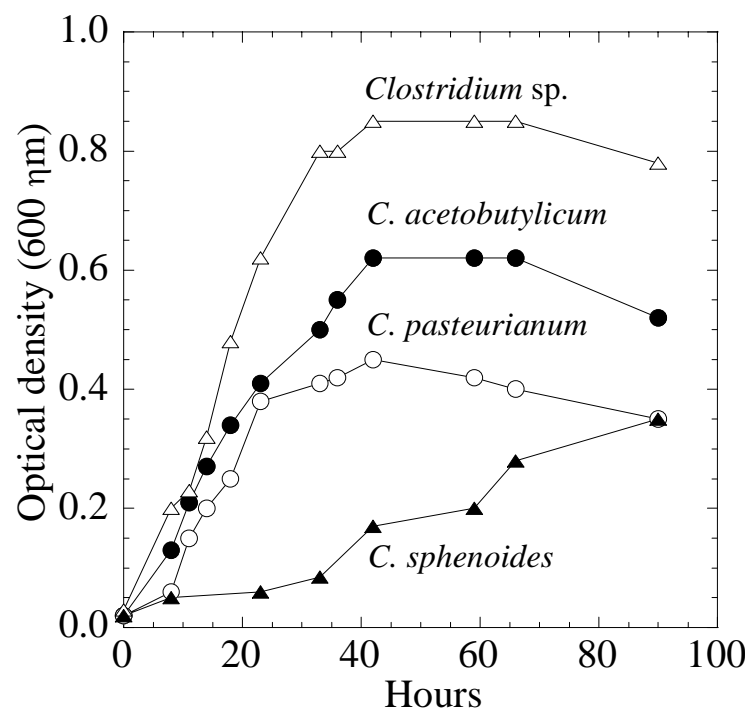

Figure 1. Growth of Clostridial isolates. isolated in this laboratory previously, $C$. sphenoides (ATCC 19403), C. acetobutylicum (ATCC 824) and C. pasteurianum (ATCC 7040) were obtained from the American Type Culture Collection.

We determined the growth profile of the bacteria, head-space gas production, change in $\mathrm{pH}$ of the medium, and identified the gaseous and liquid metabolites. Among the strains tested, Clostridium sp. grew the fastest and had the highest cell density (Fig 1) in media containing glucose. Gas chromatography (GC) analysis of the head space gases showed all strains produced $\mathrm{CO}_{2}(50 \%)$ and $\mathrm{H}_{2}(50 \%)$. The total gas production by the various isolates is shown in Figure 2. The $\mathrm{pH}$ of the medium changed from near neutral to around $\mathrm{pH} 3$ due

to production of organic acids. In contrast, the C. sphenoides cultured in Simmons Citrate 


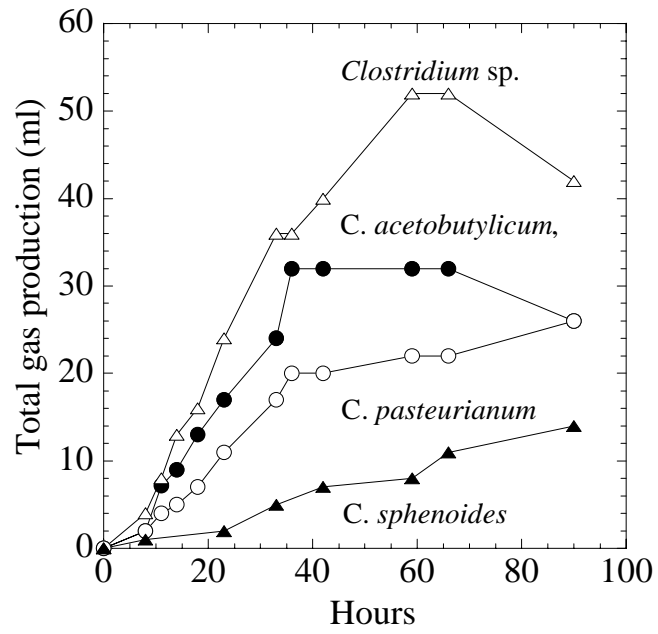

Figure 2. Headspace gas production by Clostridia.

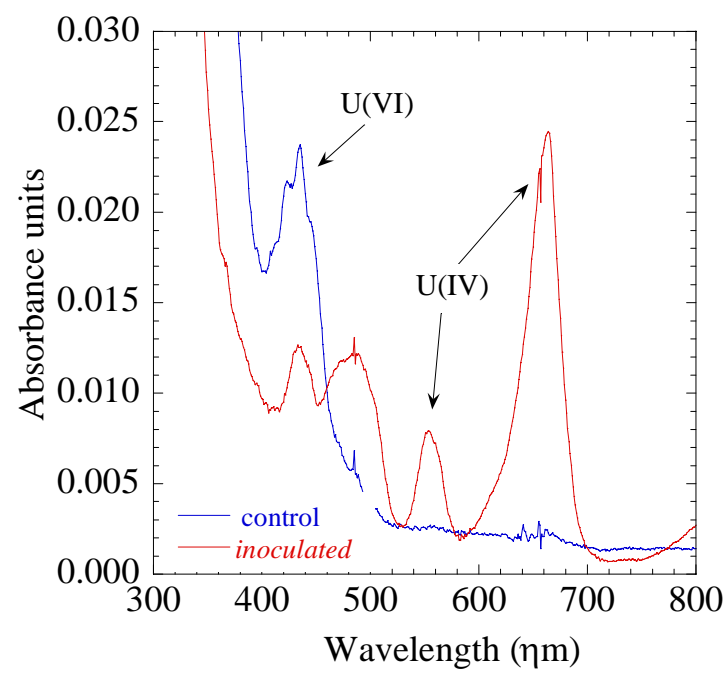

Figure 3. UV-vis spectra of U(VI) reduction by Clostridium sp.

Table 1. Rate of U(VI) reduction by Clostridia.

\begin{tabular}{lc}
\hline \multicolumn{1}{c}{ Strain } & $\begin{array}{c}\mathrm{U}(\mathrm{VI}) \text { reduction } \\
\left(\mu \mathrm{M} \mathrm{hr}^{-1} \mu \mathrm{g}^{-1} \text { protein }\right)\end{array}$ \\
\hline Clostridium sp. & 0.1 \\
C. acetobutylicum & 0.025 \\
C. pasteurianum & 0.01 \\
C. sphenoides & 0.05 \\
\hline
\end{tabular}

medium showed a slight $\mathrm{pH}$ increase due to degradation of citric acid. High performance liquid chromatography (HPLC) analysis of bacterial fermentation products showed that all strains tested produced acetic acid. In addition, Clostridium sp., $C$. acetobutylicum and $C$. pasteurianum produced isobutyric acid, while $C$. sphenoides produced butyric acid and oxalacetic acid.

Both uranium (VI)-citrate and uranium (VI)nitrate were reduced by the four isolates tested, indicating that uranium (VI) complexation with citrate did not affect the rate or extent of bacterial reduction. The $\mathrm{pH}$ of the culture did however have a significant effect on uranium reduction, with $\mathrm{pH}$ 5-6 being the optimal $\mathrm{pH}$ for uranium (VI) reduction in most cases. Clostridium sp. showed the strongest ability to reduce uranium and was less affected by culture $\mathrm{pH}$ compared with other strains. Upon addition of $\mathrm{U}(\mathrm{VI})$, Clostridium sp. immediately reduced uranium with over $60 \%$ uranium reduction within 8 hours and 90\% reduction in 24 hours. The reduction of $U$ (IV) to $U$ (VI) was confirmed using UV-vis spectra (Fig 3). Uranium (VI) reduction by all other strains occurred at a slower rate even under optimal conditions.

Our results showed that while the ability to reduce uranium is a common phenomenon among Clostridia, the differences in their ability to reduce it is evident among the strains tested. Clostridium sp. showed the highest uranium reduction which may partially be attributed to its adaptation to harsh environmental conditions such as low $\mathrm{pH}$, as well as its capacity to rapidly ferment glucose. Under optimal conditions, the estimated uranium reduction rate of each strain is shown in Table 1.

\section{BIOCHEMICAL BASIS OF URANIUM REDUCTION BY CLOSTRIDIA}

In this study, we demonstrate that the hydrogenase enzyme plays an important role in both uranium (VI) and iron (III) reduction by Clostridium sp. When hydrogen gas $\left(\mathrm{H}_{2}\right)$ was provided in the headspace of the serum bottle, either uranium (VI) or iron (III) reduction occurred 
in the presence of whole cells without carbon source. This is in contrast to the introduction of nitrogen gas $\left(\mathrm{N}_{2}\right)$ into the headspace. In the absence of whole cells, hydrogen alone could not result in either uranium (VI) or iron (III) reduction, suggesting that a hydrogenase mediated both the uranium (VI) and iron (III) reduction using hydrogen as the electron donor (Fig 4). When the hydrogenase activity was inhibited by adding copper (II), uranium (VI) reduction was not observed.
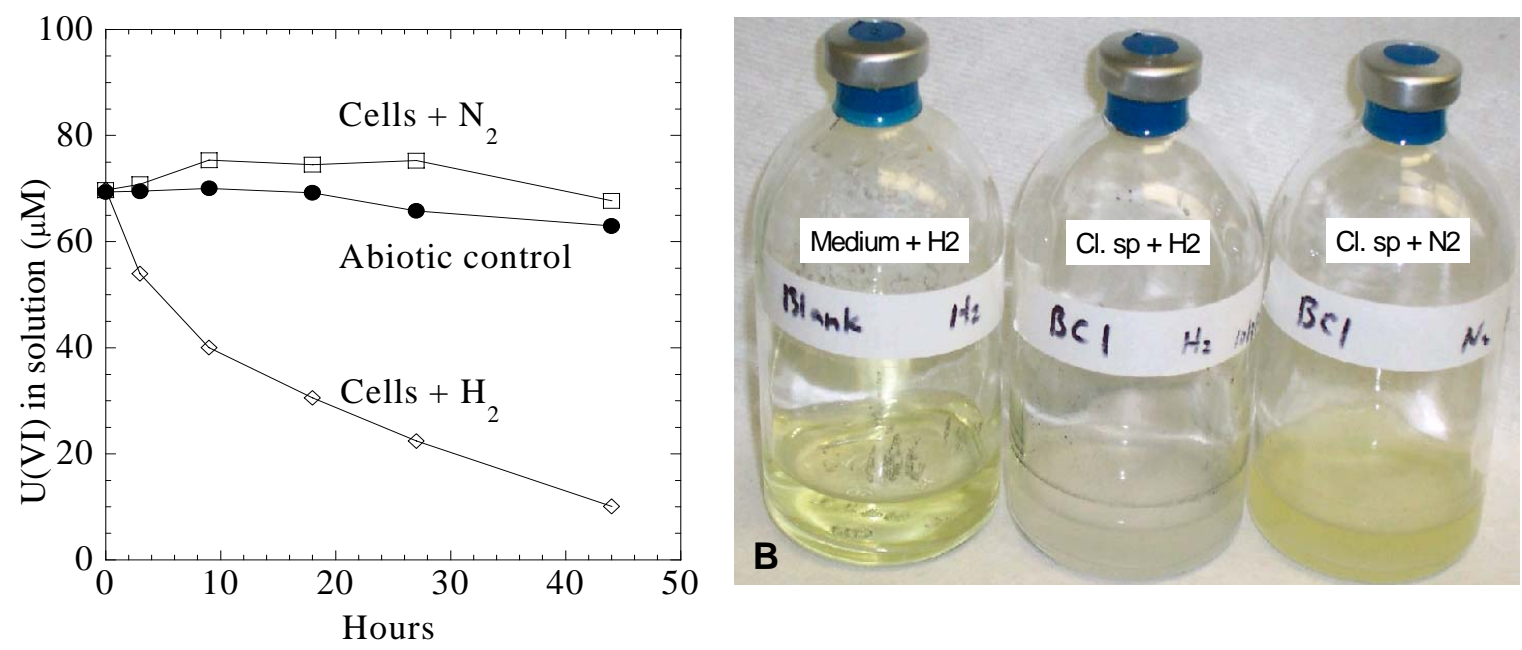

Figure 4. Hydrogen-driven reduction of U(VI) (A) and Fe(III) (B) by Clostridium sp.

\section{EFFECT OF ORGANIC LIGANDS ON THE REDOX PROPERTIES OF HEXAVALENT URANIUM}

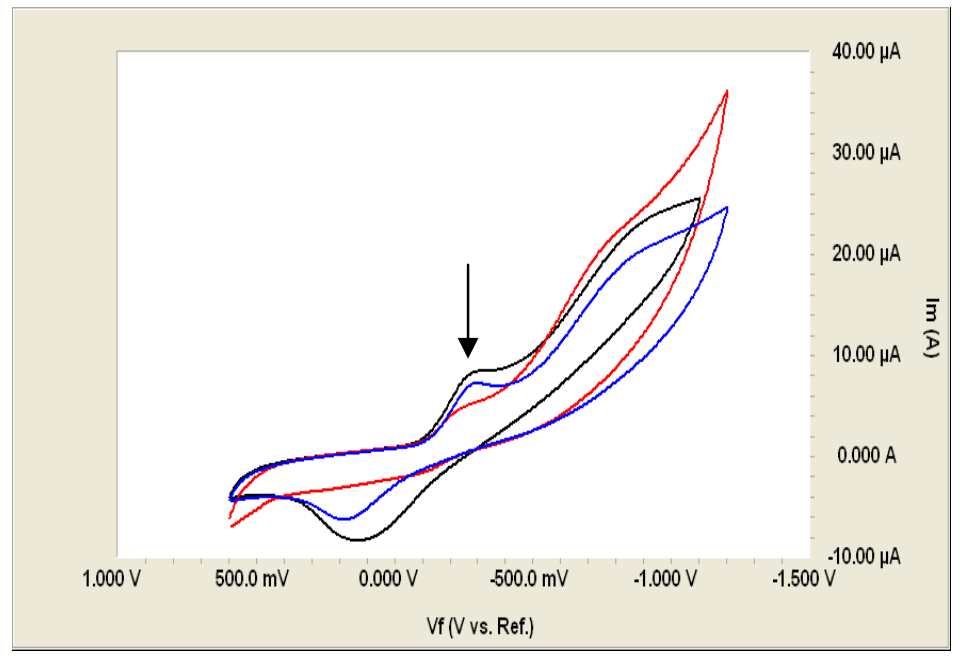

Figure 5. $\mathrm{CV}$ of $0.25 \mathrm{mM} \mathrm{UO}\left(\mathrm{NO}_{3}\right)_{2}$ complexed with acetic, phthalic and citric acids. Peak reduction currents (arrow) increases in the order $\mathrm{U}(\mathrm{VI})$-citrate $<\mathrm{U}(\mathrm{VI})$-phthalate $<\mathrm{U}(\mathrm{VI})$ acetate.
The presence of organic ligands can affect the mobility and stability of uranium. We investigated the stability of uranyl-acetate, -pthalate and -citrate complexes by cyclic voltammetry $(\mathrm{CV})$ to determine the redox potentials and mechanisms of oxidation/reduction reactions. Voltammograms (Fig.5) indicate that uranyl citrate reduction is not as reversible as reduction of uranyl acetate and uranyl phthalate. This indicates that the stability of the citrate complex is greater than the acetate or phthalate complexes.
Further studies are underway to determine the mechanism of the reaction (e.g., 


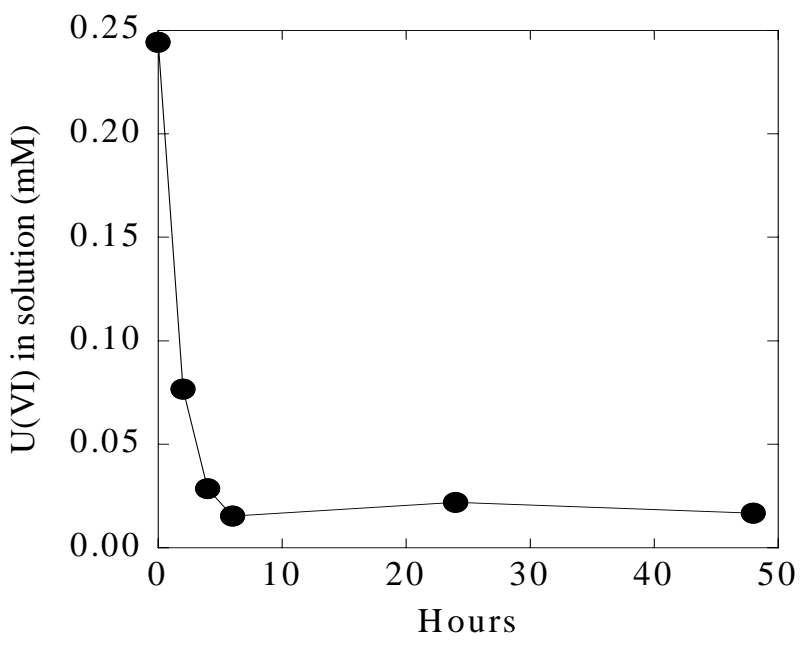

Figure 6. Extracellular U(VI) reduction by Clostridium sp.

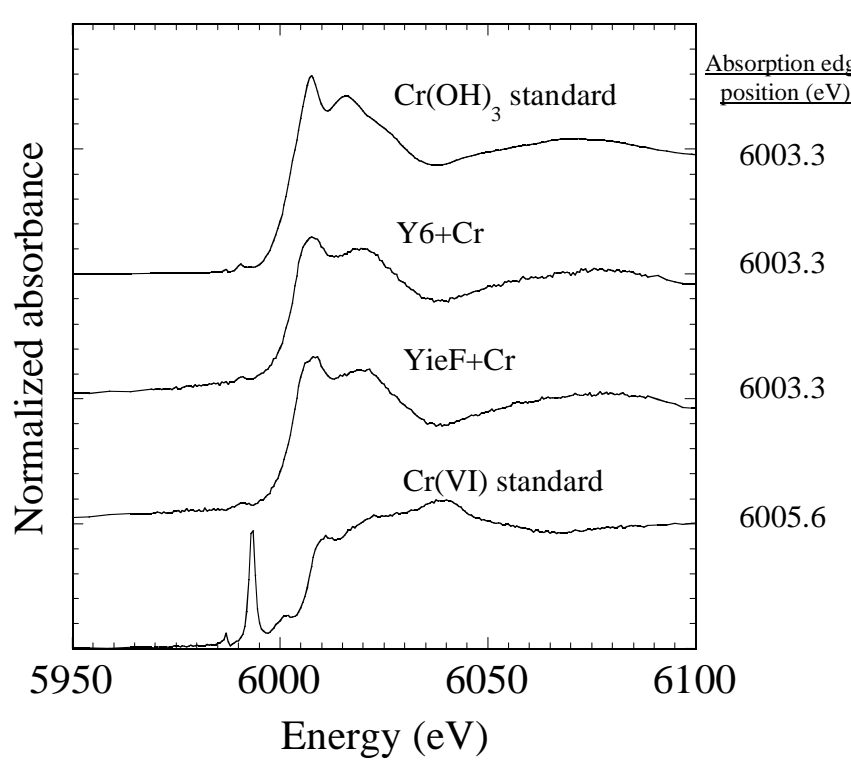

Figure 7. Comparison of peak absorption energy positions for standards containing $\mathrm{Cr}(\mathrm{III})$ and $\mathrm{Cr}(\mathrm{VI})$ and samples exposed to YieF and Y6 enzymes. XANES was performed at the $\mathrm{Cr} \mathrm{K}$ edge on enzyme samples exposed to chromate ion. one electron as opposed to two electron reduction and reoxidation).

\section{EXTRACELLULAR REDUCTION OF U(VI)}

We have designed a novel apparatus to study electron transfer reactions mediated by microorganisms and identify the mechanism involved in this process. Initial results using this experimental set-up indicate that Clostridium sp. reduced Fe (III) to Fe (II) and U(VI) to U(IV) extracellularly. The reduction of $U$ is shown in Figure 6 . Currently, studies are underway to identify the mechanisms of $U$ reduction.

\section{CHROMATE AND URANYL ION REDUCTION BY BACTERIAL ENZYMES}

Chromate and uranium reducing enzymes were isolated from bacteria using standard techniques at Stanford University. The ChrR enzyme was tested for its ability to reduce $\mathrm{Cr}$, while the YieF and Y6 enzymes were tested for both $\mathrm{Cr}$ and $\mathrm{U}$ reduction. The extent of electron transfer between the $\mathrm{Cr}(\mathrm{VI})$ and the YieF, F6 and ChrR enzymes was determined using $\mathrm{X}$-ray absorption near edge spectroscopy (XANES) analysis at the National Synchrotron Light Source (NSLS). Comparison of the absorption edge energies for the ChrR (CP and CF) and the YieF (YP and YF) treatments indicate all reduce $\mathrm{Cr}$ to the same extent (Figure 7). The extent of uranium reduction was similarly determined using the $\mathrm{M}_{\mathrm{V}}$ absorption edge. 


\section{PLANNED ACTIVITIES}

We will (i) determine the role of hydrogenase in uranium reduction, (ii) identify the mechanisms of extracellular uranium reduction by Clostridia, (iii) purify the enzymes involved in uranium reduction, and (iv) elucidate the genetic control of the enzymes and cellular factors involved in uranium reduction.

\section{INFORMATION ACCESS}

1. Francis, A.J., A.C. Matin, W. Gao, D. Chidambaram, Y. Barak, C. J. Dodge. 2006. Molecular mechanisms of uranium reduction by Clostridia. Poster presentation at 2006 Annual NABIR PI Meeting, April 19-21, 2006, Warrenton, VA.

2. Barak, Y., D. F. Ackerley, C. J. Dodge, L. Banwari, C. Alex, A. J. Francis, A. Matin. 2006. Analysis of novel soluble chromate and uranyl reductases and generation of an improved enzyme by directed evolution. Appl. Environ. Microbiol. 72: 7074-7082. 